\title{
KARAKTERISTIK ORGANOLEPTIK DENDENG DARI DAGING KAMBING BLIGON YANG DIBERI PAKAN DAUN PEPAYA (Carica papaya) BERBAGAI LEVEL
}

\author{
Jauhari', Edi Suryanto $^{2}$, dan Soeparno ${ }^{2}$
}

\section{INTISARI}

Penelitian ini bertujuan untuk mengetahui karakteristik organoleptik dendeng goreng sayat dan giling dari daging kambing yang diberi pakan daun pepaya berbagai level. Dua puluh tujuh ekor kambing betina umur sekitar enam bulan dengan berat antara $12-14 \mathrm{~kg}$ digunakan dalam penelitian ini. Kambing dipelihara dalam kandang individu dan diberi pakan daun pepaya dengan level 0,25, dan $50 \%$ selama tiga bulan. Pada akhir pemeliharaan sembilan ekor kambing dipotong dengan masingmasing perlakuan terdiri dari tiga ekor. Daging yang digunakan untuk pembuatan dendeng diambil dari otot paha (Biceps femoris, Semimembranosus dan Semitendinosus). Dua cara pembuatan dendeng, yaitu dengan disayat dan digiling. Dendeng digoreng pada suhu $137^{\circ} \mathrm{C}$ selama 3 menit dan diuji organoleptik menggunakan panelis sebanyak 30 orang. Data karakteristik organoleptik dianalisis statistik non parameterik dengan metode Kruskal-Wallis. Hasil penelitian menunjukkan bahwa level daun pepaya tidak mempengaruhi skor warna, tekstur, kekerasan rasa manis, rasa asin, dan rasa pahit dendeng goreng. Cara pembuatan mempengaruhi skor tekstur $(P<0,05)$ dan tidak mempengaruhi skor warna, kekerasan rasa manis, rasa asin, dan rasa pahit dendeng goreng. Level daun pepaya $25-50 \%$ tidak menurunkan skor intensitas dan kesukaan. Pembuatan dendeng dapat menghilangkan rasa pahit pada dendeng goreng sayat dan giling.

(Kata kunci: Kambing Bligon, Daun pepaya (Carica papaya), Dendeng goreng, Karakteristik organoleptik).

Buletin Peternakan 29 (3) : 115 - 121, 2005

\footnotetext{
${ }_{2}^{4}$ Alumnus S2 Fakultas Peternakan Universitas Gadjah Mada, Yogyakarta

${ }^{2}$ Fakultas Peternakan Universitas Gadjah Mada, Yogyakarta.
} 


\title{
ORGANOLEPTICAL CHARACTERISTICS OF DENDENG FROM MEAT OF BLIGON GOAT FED VARIOUS LEVELS OF PAPAYA LEAVES (Carica papaya)
}

\begin{abstract}
The study was conducted to investigate the organoleptical characteristics of sliced and ground fried dendeng from goat fed various level of papaya leaves. Twenty seven goats of six months old weighing $12-14 \mathrm{~kg}$ were used in this experiment. They were grown in individual pens for three months and fed papaya leaves at the level of 0,25 , and $50 \%$ of the ration. At the end of growing period nine goats were slaughtered, three goats from each dietary treatment. Dendeng was made from thigh meat (Biceps femoris, Semimembranosus, Semitendinosus) of goats. There were two methods of making dendeng, namely sliced and ground. The testing of organoleptical characteristics was carried out by 30 panelists. Data of organoleptical characteristics were tested by a non parametrical statistics as explained by Kruskal-Wallis. The results indicated that the level of papaya leaves gave no significant differences on color, texture, firmness, sweetness, saltness, and bitterness scores of fried dendeng. The method of making dendeng gave significant differences on texture scores $(\mathrm{P}<0.05)$ and gave no significant differences on color, firmness, sweetness, saltness, and bitterness scores of fried dendeng. The level of $25-50 \%$ papaya leaves did not decrease intensity scores. The methods of making dendeng could reduce bitterness of sliced and ground fried dendeng.
\end{abstract} (Keywords: Bligon goat, Papaya leaves (Carica papaya), Dendeng, Organoleptical
characteristics).

\section{Pendahuluan}

Daun pepaya dapat digunakan sebagai bahan pakan untuk ternak karena kandungan protein kasar daun pepaya kering ini cukup tinggi yaitu $13,56 \%$. Daun pepaya merupakan limbah pertanian dan perkebunan yang produksinya melimpah setiap tahun, ini dapat dimanfaatkan sebagai bahan pakan khususnya ternak kambing untuk substitusi kelangkaan hijauan di musim kemarau. Daun pepaya mempunyai khasiat yang sangat baik bagi kesehatan. Penggunaan fitobiotik dalam pakan mulai banyak digunakan. Fitobiotik dari familia Papaveraceae dapat meningkatkan beberapa fungsi metabolik yang terkait dengan nafsu makan, memperbaiki fungsi organ-organ pembantu pada tractus digestivus seperti kelenjar empedu, hati dan pankreas serta menjaga keseimbangan asam-asam amino dalam tubuh ternak (Zuprizal, 2004).

Pepaya merupakan salah satu famili Papaveraceae. Ekstrak biji pepaya di berbagai negara telah banyak dipasarkan secara luas sebagai suplemen nutrisi dengan multi manfaat, memperbaiki kondisi tubuh, meningkatkan imunnitas, memperlancar fungsi jaringan tubuh dan anti inflamatori (Mojica-Hensaw dkk., 2003), anti bakteri (Dawkins dkk., 2003), mencegah serangan protozoa pada ikan (Ekanem dkk., 2004), buah pepaya kering sebagai anti hepatotoksik (Rajkapoor dkk., 2002), pelapah batang pohon pepaya memiliki efek kontraseptif pada tikus jantan (Kusemiju dkk., 2002) dan mencegah diabetes kronis serta penyakit komplikasinya (Savickiene dkk., 2002). Pemberian tepung daun pepaya dalam ransum dapat meningkatkan bobot badan dan menurunkan jumlah oosit pada feses ayam pedaging penderita infeksi Eimeria tenella (Rudyanto, 1991).

Pertumbuhan dan perkembangan dipengaruhi oleh faktor genetik, pakan, jenis kelamin, hormon, kastrasi, lingkungan, dan manajemen (Judge dkk., 1989). Perbedaan pakan akan memberikan keragaman dalam kecepatan pertumbuhan dan komposisi tubuh. Pertambahan bobot badan harian, persentase karkas, komposisi kimia dan karakteristik fisik daging kambing yang diberi dan tanpa diberi pakan daun pepaya tidak berbeda, namun cita rasa sedikit berbeda. Rasa daging ruminansia relatif dipengaruhi oleh pakan. 
Kambing yang diberi pakan daun pepaya akan menghasilkan daging yang rasa pahit. Rasa pahit ini dapat menurunkan akseptabilitas dan menurunkan harga jual ternak. Bau dan rasa daging masak ditentukan oleh prekursor yang larut dalam air dan lemak dan pembebasan substansi atsiri (volatil) yang terdapat dalam daging. senyawa-senyawa di dalam lemak adalah spesifik untuk suatu spesies, jenis kelamin dan bisa ditimbulkan dari ingredien pakan, misalnya daun pepaya, tepung ikan dan bawang putih. Selain itu juga diabsorpsi selama pengolahan dan penyimpanan, misalnya bau deterjen, bau alat pendingin atau pembekuan, asap dan bahan tambahan (Soeparno, 2005).

Daging kambing yang diberi pakan daun pepaya kering mempunyai daging yang pahit. Upaya yang dilakukan untuk menghilangkan rasa pahit dengan pengolahan menjadi dendeng. Dua cara pembuatan dendeng ada dua, yaitu sayat dan giling, dendeng yang dihasilkan dengan cara digiling mempunyai tekstur dan warna yang lebih baik dan lebih empuk dari pada dendeng sayat, namun citarasa dendeng sayat lebih baik. Selama proses pembumbuan dan pengeringan dendeng akan terjadi pembentukan cita rasa dan aroma dendeng menjadi lebih sedap dan penurunan kadar air yang dikuti dengan perubahan komposisi kimia lainnya, untuk itu perlu dilakukan penelitian tentang karakteristik organoleptik dendeng dari daging kambing Bligon yang diberi pakan daun pepaya (Carica papaya) berbagailevel.

\section{Materi dan Metode}

Dua puluh tujuh ekor kambing Bligon betina umur sekitar enam bulan dipelihara dalam kandang individu. Kambing diberi pakan daun pepaya $0 \%(\mathrm{P} 0), 25 \%(\mathrm{P} 1)$ dan $50 \%(\mathrm{P} 2)$ selama tiga bulan. Pada akhir penelitian sembilan ekor kambing dipotong yang masing-masing terdiri dari tiga ekor setiap perlakuan. Daging bagian paha (Semimembranosus, Semitendinosus, Biceps femoris) diambil dan diproses untuk pembuatan dendeng dan pengujian.

Pembuatan dendeng dilakukan dengan cara, yaitu daging disayat tipis-tipis. Preparasi bumbu yang digunakan untuk $1 \mathrm{~kg}$ daging yang dimodifikasi dari Hadiwiyoto (1994) dan Purnomo (1997), yaitu $300 \mathrm{~g}$ gula jawa, $30 \mathrm{~g}$ garam dapur, $20 \mathrm{~g}$ ketumbar, $20 \mathrm{~g}$ bawang putih, $10 \mathrm{~g}$ laos dan $10 \mathrm{~g}$ jinten. Dendeng sayat adalah. daging disayat dengan pisau yang tajam untuk mendapatkan sayatan daging yang lebar dengan ketebalan 2-3 mm. Sayatan-sayatan daging direndam dalam larutan bumbu dan ditiriskan. Dendeng sayat dioven pada suhu $50^{\circ} \mathrm{C}$ selama 18 jam. Dendeng kering digoreng, lalu diuji organoleptik dengan panelis sebanyak 30 orang.

Uji organoleptik dengan menggunakan metode Larmond 1977 (Sudibiyo et al., 1991). Sampel dendeng mentah dipotong-potong dengan ukuran $5 \times 3 \mathrm{~cm}^{2}$. Sampel dendeng direndam pada air hangat $\left(50^{\circ} \mathrm{C}\right)$ selama 2 menit, digoreng pada suhu $137^{\circ} \mathrm{C}$ selama 5 menit dan sampel disajikan secara acak dengan memberikan kode tertentu. Uji organoleptik yang dilakukan terdiri dari lima skor intensitas seperti tertera pada Tabel 1 dan 2.

Data karakteristik organoleptik dendeng diuji statistik non parameterik dengan metode Kruskal-Wallis (Alois, 1987).

\section{Hasil dan Pembahasan}

Data lemak dendeng sayat dan giling dari daging kambing yang diberi pakan daun papaya tertera pada Tabel 3.

Hasil analisis statistik menunjukkan bahwa level daun pepaya dalam pakan dan cara pembuatan dendeng tidak berpengaruh nyata terhadap kadar lemak dendeng pada Tabel 3 . Perbedaan yang tidak nyata kadar lemak antara dendeng sayat dan giling disebabkan karena penggilingan daging mengakibatkan protein pecah menjadi partikel-partikel yang lebih kecil dan melindungi air dan lemak. Kadar lemak dan protein dendeng berbanding terbalik dengan kadar lemak dan protein dendeng, sehingga semakin tinggi kadar lemak akan menurunkan kadar air dendeng. Kadar air juga berhubungan dengan protein daging, yaitu sifat hidrofilik protein daging dalam mengikat molekulmolekul air (Soeparno, 2005).

Data karakteristik organoleptik dendeng sayat dan giling dari daging kambing Bligon yang diberi pakan daun pepaya yang meliputi 
Tabel 1. Skor intensitas warna, tekstur, dan kekerasan (Intensity scores of color, texture, and firmness)

\begin{tabular}{lrlll}
\hline Warna (Color) & \multicolumn{1}{c}{ Tekstur (Texture) } & \multicolumn{1}{c}{ Kekerasan (Firmness) } \\
\hline 1. Hitam (Black) & 1. & Sangat kasar (Very & 1. & Sangat keras (Very tougth) \\
2. Coklat tua (Dark brown) & coarse) & 2. Keras (Tougth) \\
3. Merah kecoklatan & 2. Kasar (Coarse) & 3. & Agak empuk (Light tender) \\
(Browness red) & 3. Agak halus (Light fine) & 4. Empuk (Tender) \\
4. Merah (Red) & 4. Halus (Fine) & 5. Sangat empuk (Very tender) \\
5. Merah muda (Light red) & 5. Sangat halus (Very fine) & & \\
\hline
\end{tabular}

Tabel 2. Skor intensitas rasa (Intensity scores of taste)

\begin{tabular}{|c|c|c|c|c|c|c|}
\hline \multirow[t]{2}{*}{$\begin{array}{l}\text { Variabel } \\
\text { (Variable) }\end{array}$} & \multicolumn{5}{|c|}{$\begin{array}{l}\text { Skor intensitas rasa } \\
\text { (Intensity score of taste) }\end{array}$} & \multirow[t]{2}{*}{$\begin{array}{l}\text { Bahan-bahan per liter aquades } \\
\text { (Ingredients per liter) }\end{array}$} \\
\hline & 1 & 2 & 3 & 4 & 5 & \\
\hline Manis (Sweet) & 60 & 45 & 30 & 15 & 0 & g gula pasir (Sucrose) \\
\hline Asin (Salt) & 6,0 & 4,5 & 3,0 & 1,5 & 0 & $\mathrm{~g}$ garam dapur (Salt) \\
\hline Pahit (Bitter) & 6,0 & 4,5 & 3,0 & 1,5 & 0 & $\begin{array}{l}\mathrm{g} \text { daun pepaya segar (Fresh } \\
\text { papaya leaf juice) }\end{array}$ \\
\hline
\end{tabular}

skor intensitas wama, tekstur dan kekerasan tertera pada Tabel 4 dan skor intensitas rasa manis, asin, dan pahit tertera pada Tabel 5 .

Hasil analisis statistik menunjukkan bahwa level daun pepaya dalam pakan dan cara pembuatan dendeng tidak mempengaruhi skor intensitas warna dendeng sayat maupun giling pada Tabel 4. Skor intensitas warna sayat tertinggi $\mathrm{P} 0(3,17)$ dan terendah $\mathrm{P} 1 \quad(2,83)$, sedangkan pada dendeng giling tertinggi $\mathrm{P} 0$ dan P2 $(3,03)$ dan terendah $(2,87)$. Skor intensitas warna dendeng sayat lebih rendah daripada dendeng giling.

Warna dendeng giling yang lebih gelap diduga disebabkan karena penggilingan dapat membuat serabut-serabut jaringan menjadi halus dan cairan daging yang mengandung hemoglobin akan keluar kepermukaan, protein akan bereaksi dengan glukosa yang berasal dari gula akibatnya terbentuk warna kecoklatan (Maillard). Warna produk dendeng dipengaruhi oleh kadar gula dalam bahan-bahan bumbu dan suhu yang digunakan dalam proses pengeringan. Warna coklat kemerahan merupakan ciri khas daging proses atau curing

Hasil analisis statistik menunjukkan bahwa level daun pepaya dalam pakan tidak mempengaruhi skor intensitas tekstur dendeng sayat maupun giling, sedangkan cara pembuatan dendeng mempengaruhi skor intensitas tekstur dendeng $(\mathrm{P}<0,05)$ pada Tabel 4. Perbedaan skor tekstur dendeng diduga disebabkan karena terjadinya perbedaan kadar lemak pada dendeng sayat dan giling segar maupun goreng yang berbeda nyata. Selain itu skor intensitas tekstur dendeng juga diduga disebabkan oleh pengeringan dendeng giling rambatan panas dari permukaan ke bagian dalam lebih cepat sehingga penyebaran panas lebih seragam.

Nilai skor tekstur dendeng sayat tertinggi P0 $(2,47)$ dan terendah P2 $(2,27)$, sedangkan pada dendeng giling tertinggi $\mathrm{PO}(3,10)$ dan terendah P2 $(2,83)$. Secara rata-rata skor intensitas tekstur dendeng giling lebih baik dibanding dendeng sayat. Secara visual skor intensitas tekstur dendeng sayat berada pada skor 
Tabel 3. Rata-rata kadar lemak dendeng sayat dan giling dari daging kambing Bligon berdasarkan level daun pepaya (\%) (Fat content means of sliced and ground dendeng from meat of Bligon goat fed various levels of papaya leaves (\%))

\begin{tabular}{lcccc}
\hline $\begin{array}{c}\text { Pembuatan dendeng } \\
\text { (Making dendeng) }\end{array}$ & \multicolumn{2}{c}{ Level daun papaya (Levels of papaya leaves) } & \multirow{2}{*}{$\begin{array}{c}\text { Rata-rata } \\
\text { (Means) }\end{array}$} \\
\cline { 2 - 4 } & $0 \%(\mathrm{P} 0)$ & $25 \%(\mathrm{P} 1)$ & $50 \%(\mathrm{P} 2)$ & \\
\hline Sayat (Sliced) & 5,97 & 4,15 & 7,09 & 5,74 \\
Giling (Ground) & 5,11 & 4,63 & 3,46 & 4,40 \\
\hline Rata-rata $^{\text {ns }}$ (Means) & 5,54 & 4,39 & 5,27 & \\
\hline
\end{tabular}

${ }^{\text {ns }}$ Non signifikan (Not significant).

Tabel 4. Rata-rata skor intensitas warna, tekstur, dan kekerasan dendeng sayat dan giling dari daging kambing Bligon berdasarkan level daun papaya (Intensity score means of color, texture, and firmness of sliced and ground dendeng from meat of Bligon goat fed various level of papaya leaves)

\begin{tabular}{|c|c|c|c|c|}
\hline \multirow{2}{*}{$\begin{array}{c}\text { Pembuatan } \\
\text { dendeng (Making } \\
\text { dendeng) }\end{array}$} & \multirow{2}{*}{$\begin{array}{l}\text { Level daun pepaya } \\
\text { (Levels of papaya } \\
\text { leaves) }\end{array}$} & \multicolumn{3}{|c|}{$\begin{array}{l}\text { Skor intensitas karaketeristik organoleptik } \\
\text { (intensity score of organoleptik characteristics) }\end{array}$} \\
\hline & & $\begin{array}{l}\text { Warna } \\
\text { (Color) }\end{array}$ & $\begin{array}{l}\text { Tekstur } \\
\text { (Texture) }\end{array}$ & $\begin{array}{l}\text { Kekerasan } \\
\text { (Firmness) }\end{array}$ \\
\hline \multirow[t]{3}{*}{ Sayat (Sliced) } & $0 \%(\mathrm{P} 0)$ & 3,17 & $2,47^{a}$ & 2,80 \\
\hline & $25 \%$ (P1) & 2,83 & $2,30^{\mathrm{a}}$ & 2,77 \\
\hline & $50 \%(\mathrm{P} 2)$ & 3,00 & $2,27^{\mathrm{a}}$ & 2,80 \\
\hline \multirow[t]{3}{*}{ Giling (Ground) } & $0 \%(\mathrm{P} 0)$ & 3,03 & $3,10^{\mathrm{b}}$ & 3,43 \\
\hline & $25 \%$ (P1) & 2,87 & $3,08^{\mathrm{b}}$ & 3,40 \\
\hline & $50 \%(\mathrm{P} 2)$ & 3,03 & $2,83^{b}$ & 3,70 \\
\hline
\end{tabular}

${ }^{\mathrm{ab}}$ Superskrip yang berbeda pada kolom yang sama menunjukkan perbedaan yang sangat nyata $(\mathrm{P}<0,05)$ (Means with different superscripts in a same column are significantly different $(P<0.05))$.

intensitas kasar (2), dan dendeng giling berada pada skor intenstas agak kasar (3). Konsentrasi garam $30 \%$ dapat menyebabkan tekstur menjadi kering dan kasar, sebaliknya dengan gula. Tekstur dendeng ini dipengaruhi oleh kadar gula yang terserap oleh daging pada saat curing .

Hasil analisis statistik menunjukkan bahwa level daun pepaya dalam pakan dan cara pembuatan dendeng tidak mempengaruhi skor intensitas kekerasan dendeng sayat maupun giling pada Tabel 4. Skor intensitas kekerasan dendeng sayat tertinggi $\mathrm{P} 1(2,77)$ dan terendah
$\mathrm{P} 0$ dan $\mathrm{P} 2(2,80)$, sedang pada dendeng giling tertinggi P2 $(3,70)$ dan terendah P1 $(3,40)$. Skor intensitas kekerasan dendeng sayat lebih keras dibandingkan dendeng giling.

Hasil analisis statistik menunjukkan bahwa level daun pepaya dalam pakan dan cara pembuatan dendeng tidak mempengaruhi skor intensitas rasa manis dendeng sayat maupun giling pada Tabel 5. Skor rasa manis dendeng sayat tertinggi $\mathrm{P} 0$ dan $\mathrm{P} 1(3,13)$ dan terendah $\mathrm{P} 2$ $(3,10)$, sedangkan dendeng giling tertinggi $\mathrm{P} 0$ $(3,80)$ dan terendah P1 $(3,67)$. Skor intensitas 
manis dendeng sayat lebih rendah daripada dendeng giling, kisaran ini masih berada pada intensitas agak manis sampai manis (3-4).

Hasil analisis statistik menunjukkan bahwa level daun pepaya dalam pakan dan cara pembuatan dendeng tidak mempengaruhi skor intensitas rasa asin dendeng sayat maupun giling pada Tabel 5. Skor rasa asin dendeng sayat tertinggi P0 $(3,27)$ dan terendah P1 $(3,13)$, sedangkan dendeng giling tertinggi $\mathrm{P} 2(3,13)$ dan terendah P0 $(2,90)$. Skor intensitas rasa asin, dendeng sayat lebih asin daripada dendeng giling dengan kisaran berturut-turut adalah 3,13-3,27 dan $2,90-3,13$, kisaran ini masih berada pada intenstas agak asin (3).

Hasil analisis statistik menunjukkan bahwa level daun pepaya dalam pakan dan cara pembuatan dendeng tidak mempengaruhi skor intensitas rasa pahit dendeng sayat maupun giling pada Tabel 5. Skor rasa pahit dendeng sayat tertinggi $\mathrm{P} 0(4,37)$ dan terendah $\mathrm{Pl}$ giling $(4,13)$, sedangkan dendeng giling tertinggi $(4,57)$ dan terendah $(4,13)$. Skor intensitas rasa pahit berada pada skor intensitas rasa tidak pahit sampai sangat tidak pahit (4-5). Kisaran skor intensitas pahit dendeng sayat dan giling berturut-turut adalah 4,13-4,37 dan 4,13-4,57.

Rasa dan aroma daging olahan dapat dipengaruhi bahan tambahan pada saat pengolahan. Hal ini sesuai Sudarmadji dkk. (1989) bahwa pemberian gula dapat memperbaiki flavor bahan makanan sehingga rasa manis yang timbul dapat meningkatkan kelezatan, memperbaiki tekstur bahan makanan misalnya kenaikan viskositas produk. Penambahan garam dan gula pada bahan pangan dapat mereduksi rasa pahit. Selain itu perbedaan rasa yang tidak nyata ini diduga disebabkan oleh perbedaan kadar lemak yang tidak berbeda nyata. Menurut Soeparno (2005) bahwa kadar lemak memegang peran penting dalam menentukan cita rasa dan aroma daging. Daging yang hamper tidak mengandung marbling mempunyai cita rasa dan aroma kurang baik daripada daging yang cukup marbling.

\section{Kesimpulan}

Kesimpulan yang dapat diambil dari penelitian ini adalah:

1. Pemberian daun pepaya $25-50 \%$ tidak menurunkan skor intensitas dendeng dan kesukaan panelis terhadap produk dendeng. Dendeng yang dibuat dengan cara digiling dapat meningkatkan tekstur dendeng,

2. Pembuatan dendeng dapat menghilangkan rasa pahit pada daging kambing yang diberi pakan daun pepaya.

Tabel 5. Rata-rata skor intensitas rasa dendeng sayat dan giling dari daging kambing Bligon berdasarkan level daun papaya (Intensity score means of taste of slice and ground dendeng from meat of Bligon goat fed various levels of papaya leaves)

\begin{tabular}{|c|c|c|c|c|}
\hline \multirow{2}{*}{$\begin{array}{c}\text { Pembuatan } \\
\text { dendeng (Making } \\
\text { dendeng) }\end{array}$} & \multirow{2}{*}{$\begin{array}{c}\text { Level daun } \\
\text { pepaya (Levels of } \\
\text { papaya leaves) }\end{array}$} & \multicolumn{3}{|c|}{ Skor intensitas rasa (Intensity score of taste) } \\
\hline & & Manis (Sweet) & (Salt) & Pahit (Bitter) \\
\hline \multirow[t]{3}{*}{ Sayat (Sliced) } & $0 \%(\mathrm{P} 0)$ & 3,13 & 3,27 & 4,37 \\
\hline & $25 \%(\mathrm{Pl})$ & 3,13 & 3,13 & 4,27 \\
\hline & $50 \%(\mathrm{P} 2)$ & 3,10 & 3,17 & 4,13 \\
\hline \multirow[t]{3}{*}{ Giling (Ground) } & $0 \%(\mathrm{P} 0)$ & 3,80 & 2,90 & 4,57 \\
\hline & $25 \%(\mathrm{P} 1)$ & 3,67 & 3,10 & 4,13 \\
\hline & $50 \%(\mathrm{P} 2)$ & 3,77 & 3,13 & 4,42 \\
\hline
\end{tabular}

Non signifikan (Not significant). 


\section{Saran}

Test sensoris perlu ditindak lanjuti mengingat masih sedikitnya informasi penelitian mengenai daya sensoris konsumen dan perlu dikembangkan dengan mengikut sertakan konsumen dalam mengontrol kualitas produk daging yang beredar di pasaran. Ini dapat terealisasikan bila konsumen lebih aktif memberi masukan pada Lembaga Konsumen Indonesia (LKI) yang bekerjasama dengan Direktorat Jenderal Pengawasan Obat dan Makanan (Dirjen POM).

\section{Daftar Pustaka}

Alois, E. B. L. 1987. Statistiche Methoden in der Ti erproduktion. Eine Anwendungsorientierte Einfuhrung. Osterr. Agrarverlag Wien.

Dawkins, G., H. Hewitt, Y. Wint, P. C. Obiefuna, and B. Wint. 2003. Antibacterial Effects of Carica papaya Fruit on Common Wound Organisms. West Indian Med. J. 2003 Dec. $52(4): 290-2$.

Ekanem, A. P., A. Obiekezie, W Kloas, and K. Knopf. 2004. Effects of Crude Extracts of Mucuna pruriens (fabaceae) and Carica papaya (caricaceae) Against the Protozoan Fish Parasite Ichthyophthirius multifiliis. Parasitol Res. 2004. Mar. 92 (5):361-6. Epub 2004 Jan. 21.

Hadiwiyoto, S. 1994. Studi Pengolahan Dendeng dengan Menggunakan Oven Pengering Rumah Tangga. Bulletin Peternakan. Fakultas Teknologi Pertanian, Universitas Gadjah Mada. Yogyakarta.

Judge, M. D., E. D. Aberle, J. C. Forrest, H. B. Hedrick, and R. A. Merkel. 1989. Principles of Meat Science. $2^{\text {nd }}$ ed. Kendall/Hunt Publishing Co., Dubuque., lowa. $351 \mathrm{p}$.

Kusemiju, O., C. Noronha, and J. Cardier. 2002. The Effects of Crude Extract of Bark of
Carica papaya on Seminiferous tubules of Male Sprague-dawley Rats. Niger Postgrad. Med. J. 2002. Dec. 9(4): 205-9. Mojica-Henshaw, M. P., A. D. Francisco, F. De Guzman, and X. T. Tigno. 2003. Possible Immonomodulatory Actions of Carica papaya Seed Extract. Clin Hemoheol Microcirc. 2003;29(3-4):219-29.

Purnomo, H. 1997. Aplikasi Kromatografi Gas dalam Pengukuran Oksidasi Lemak Dendeng. Laporan Penelitian. Fakultas Peternakan, UNIBRAW. Malang. 49 hal.

Rajkapoor, B., B. Jayakar, S. Kavimani, and N. Murugesh. 2002. Effect of Dried Fruits of Carica papaya Linn on Hepatotoxicity. Biol. Pharm. Bull. 2002. Dec; 25(12) : 1645-6.

Rudyanto, M. D. 1991. Effek Pemberian Serbuk Pepaya dalam Ransum terhadap Pertambahan Berat Badan dan Jumlah Oosit dalam Tinja Ayam Pedaging Penderita Infeksi Eimeria tenella. Tesis S-2.PPs UGM. Yogyakarta.

Savickiene, N., A. Dagylite, A. Lukosius, and V. Zitkevicius. 2002. Importance of Biologically Active Components and Plants in the Prevention of Complications of Diabetes mellitus. Medicina (Kaunas) 2002.38(10): 970-5.

Soeparno. 2005. Ilmu dan Teknologi Daging. Cetakan Keempat. Gadjah Mada University Press. Yogyakarta.

Sudarmadji, S., R. Kasmidji, Sardjono, D. Wibowo, S. Margono, dan E. S. Rahayu. 1989. Mikrobiologi Pangan. PAU Pangan dan Gizi Universitas Gadjah Mada. Yogyakarta.

Sudibiyo, S., I. A. Durini, N. M. Yura, dan A. M. A. Widiyantoro. 1991. Sifat Sensoris Pangan. PAU Pangan dan Gizi. UGM Press. Yogyakarta.

Zuprizal. 2004. Antibiotik, Probiotik, dan Fitobiotik dalam Pakan Unggas. Ilmiah Populer. Majalah Poultry Indonesia. Edisi 284, Jan. 2004. Jakarta. 